De Jure: Jurnal Hukum dan Syari'ah

Vol. 12, No. 2, Desember 2020, h. 156-175

ISSN (Print): 2085-1618, ISSN (Online): 2528-1658

DOI: http://dx.doi.org/10.18860/j-fsh.v12i2.10186

Available online at http://ejournal.uin-malang.ac.id/index.php/syariah

\title{
Urgency of Legal Pluralism Study for Students of Sharia and Law Faculty After Changes of Academic Degree
}

\author{
Yayan Sopyan \\ UIN Syarif Hidayatullah Jakarta, Indonesia \\ Yayan_sopyan@uinjkt.ac.id
}

\section{Abstract:}

Changes in Academic Degrees through Regulation of the Minister of Religion No. 33 of 2016 from Bachelor of Islamic Law to Bachelor of Law must be taken seriously by making concrete efforts to improve the quality of graduates. This regulation responds to the demands of a competitive job market. The consequence is that graduates of the Faculty of Sharia and Law have just not academic skills in the fields of Sharia and law at the same time but also have legal proficiency in the form of sensitivity to the value of justice that lives in society. Globalization accelerates social interaction. Indonesia is inevitably a plural country in which various legal systems are practiced, from customary law, religious law, national law, and international law. This study aims to analyze the reasons for the importance of legal pluralism studies taught to students of the Faculty of Sharia and law. This type of research is explanative and exploratory research. The results of this study indicate that the study of legal pluralism in the Faculty of Sharia and Law is still minimal and only inserted in certain sub-subjects. Even though the existence of this legal pluralism course is very urgent so that students have a sensitivity to the sense of justice that is the essence of law graduates, the implementation of it, legal pluralism must be an independent course or inserted into several relevant subjects.

Keywords: Legal-Pluralism; Change of Bachelor's Degree; improving the quality of graduates
Abstrak:
Perubahan Gelar Akademik melalui Peraturan Menteri Agama No 33 tahun 2016 dari Sarjana Hukum Islam menjadi Sarjana Hukum harus ditangapi dengan serius dengan melakukan upaya kongkret untuk meningkatkan mutu lulusan. Peraturan ini merespon dari tuntutan pasar kerja yang kompetitif. Konsekuensinya adalah lulusan Fakultas Syariah dan Hukum bukan saja memiliki kemampuan akademik dibidang ilmu Syariah dan ilmu hukum sekaligus, tetapi juga memiliki kemahiran hukum berupa kepekaan terhadap nilai keadilan yang hidup di masyarakat. Globalisasi mempercepat terjadinya 
interaksi sosial. Tidak dapat dielakkan bahwa Indonesia merupakan negara plural yang didalamnya dipraktikkan berbagai system hukum mulai dari hukum adat, hukum agama, hukum nasional, dan hukum internasional. Penelitian ini bertujuan untuk menganalisis alasan-alasan pentingnya kajian pluralism hukum diajarkan kepada mahasiswa Fakultas Syariah dan hukum. Jenis penelitian ini merupakan penelitian eksplanatif dan juga eksploratif. Hasil penelitian ini menunjukkan bahwa kajian pluralism hukum di Fakultas Syariah dan Hukum masih minim dan hanya disisipkan dalam submatakuliah tertentu. Padahal keberadaan matakuliah legal pluralism ini sangat urgen agar mahasiswa memiliki kepekaan terhadap rasa keadilan yang menjadi esensi dari sarjana hukum. Dalam implementasinya, pluralism hukum harus menjadi matakuliah yang mandiri, atau disisipkan pada beberapa matakuliah yang relevan.

Kata Kunci: Pluralisme Hukum, Perubahan Gelar Sarjana, peningkatan mutu lulusan.

\section{Introduction}

Indonesia, as a country with the largest Muslim population in the world ${ }^{1}$ with a diversity of religions, languages, and ethnicities, ${ }^{2}$ has three sources of law, namely Islamic Law, Customary Law, and Western $\mathrm{Law}^{3}$ Dutch colonial heritage. ${ }^{4}$ In Indonesia, Legal-pluralism is strongly affected by the culture of Indonesian society that is very plural and diverse. ${ }^{5}$ As a home, more than 265.0 million inhabitants ${ }^{6}$ and 269.6 million people (estimated in 2020) million people with various ethnicities, and religions, Indonesia is indeed a country that has the advantage of Legal-pluralism. Because it is a conditio sine qua non in Indonesian law, ${ }^{7}$ Pluralistic features also occur in the legal domain. Over the centuries, the Islamic legal system, the customary law system, and the Western legal system have influenced the building of the legal system in Indonesia. The three legal systems have affected and

\footnotetext{
${ }^{1}$ Estimated that 229 million Muslims are there. This is $87.2 \%$ of Indonesia's population of 263 million people. Or about $13 \%$ of the world's Muslim population. Muslims in Indonesia consist of $99 \%$ Sunnis, 0.5\% Shia, and 0.3\% Ahmadiyah. 'Data Populasi Penduduk Muslim 2020: Indonesia Terbesar di Dunia', IBTimes.ID (blog), 8 April 2020, https://ibtimes.id/data-populasi-penduduk-muslim-2020-indonesiaterbesar-di-dunia/.

2 Novita Dewi Masyithoh, 'DIALEKTIKA PLURALISME HUKUM: Upaya Penyelesaian Masalah Ancaman Keberagaman dan Keberagamaan di Indonesia', Walisongo: Jurnal Penelitian Sosial Keagamaan 24, no. 2 (15 December 2016): 359-78, https://doi.org/10.21580/ws.24.2.1289; Nurcholish Madjid, Islam: Doktrin \& Peradaban (Jakarta: Gramedia Pustaka Utama, 2019), 177.

${ }^{3}$ Syaifullahil Maslul and Ahmad Arif, 'Hukum Islam dan Politik Hukumnya dalam Hukum Nasional', AlBayyinah 3, no. 1 (31 July 2019): 15-27.

4 Eddy O.S. Hiariej, 'Pembaharuan Hukum Publik Dan Hukum Privat', in Memperkuat Peradaban Hukum Dan Ketatanegaraan Indonesia, ed. Imron and Festy Rahma Hidayati (Jakarta: Sekretaris Jenderal Komisi Yudisial, 2019), 241.

5 Murdan Murdan, 'Pluralisme Hukum (Adat dan Islam) di Indonesia', Mahkamah: Jurnal Kajian Hukum Islam 1, no. 1 (3 June 2016), https://doi.org/10.24235/mahkamah.v1i1.573.

6 Badan Pusat Statistik, 'Sensus Pendduk Indonesia', accessed 27 December 2020, https://www.bps.go.id/indikator/indikator/view_data_pub/0000/api_pub/50/da_03/1.

7 Yu Un Opusunggu, 'Arti Penting Hukum Antartata Hukum untuk Indonesia', Jurnal Rechts Vinding: Media Pembinaan Hukum Nasional 7, no. 2 (31 August 2018): 147, https://doi.org/10.33331/rechtsvinding.v7i2.262.
} 
changed on it is more pluralistic all the time until now. Even the harmonious use of Islamic law and customary law in the judiciary has been practicing in real terms. ${ }^{8}$

It begins with a pluralistic society and interacts with one another according to their identity. ${ }^{9}$ Every community is not born from a single value system (mono value) ${ }^{10}$ however, there are various value systems in the form of culture, religion, custom, ethnicity, or race. More diversity, more potential for conflict. ${ }^{11}$ However, it is not something that should avoid, but it is a valuable asset that complements each other towards perfection. Its value systems can be managed well through the perspective of it, openness, and without forgetting convinced values as part of social identity. ${ }^{12}$ In a conceptual framework, legal-pluralism has become a long debate in the study of law and society in Indonesia. ${ }^{13}$ Studies in the colonial period, the early days of independence to contemporary Indonesia confirm that this realm has never run out of interest to study. ${ }^{14}$ Likewise, the meaning is also continuously changing. ${ }^{15}$ However, in a practical setting, the implementation of the values of legal-pluralism has not been successful. ${ }^{16}$ Therefore, serious efforts are needed to implement it. And the most effective way to apply it is through education. If legalpluralism is a significant material that prospective law graduates must study to form a law graduate who is aware of pluralism term, then what efforts have and must be made by the Faculty of Sharia and Law to achieve it? It is where the aim of the study in this article.

Many articles and researchs on legal-pluralism have been carrying out, because this issue is still relevant to be disclosed, especially in the globalization era. However, the problem of legal pluralism education in tertiary institutions, especially in the faculty of Sharia and law, as far as the author has conducted

\footnotetext{
${ }^{8}$ Mokhammad Najih, 'Dilemma Legal Pluralism in Indonesia: Prospects and Role of Islamic Law in the National Legal Reform' (Religion, Law, and Social Stability, Brighman Young University, Utah, US, 2016).

9 Gora Kunjana, 'Pluralisme Hukum Wujud Harmonisasi Keberagaman', investor.id, accessed 27 December 2020, https://investor.id/archive/pluralisme-hukum-wujud-harmonisasi-keberagaman.

${ }^{10}$ Dedy Sumardi, 'Islam, Pluralisme Hukum dan Refleksi Masyarakat Homogen', Asy-Syir'ah: Jurnal Ilmu Syari'ah dan Hukum 50, no. 2 (1 December 2016): 481-504, https://doi.org/10.14421/asysyir'ah.2016.502-08.

${ }_{11}$ Siradjuddin Siradjuddin, 'Akar-Akar Konflik Fundamental Perspektif Ekonomi Politik', Jurnal Iqtisaduna 1, no. 2 (19 December 2015): 17-39, https://doi.org/10.24252/iqtisaduna.v1i2.1192.

${ }_{12}$ Muhammad Nizar Kherid and Fifiana Wisnaeni, 'Pluralism Justice System Dalam Penyelesaian Masalah Kebebasan Beragama', Masalah-Masalah Hukum 48, no. 4 (16 October 2019): 385-392-392, https://doi.org/10.14710/mmh.48.4.2019.385-392.

${ }^{13}$ M. Misbahul Mujib, 'Memahami Pluralisme Hukum Di Tengah Tradisi Unifikasi Hukum: Studi Atas Mekanisme Perceraian Adat', Supremasi Hukum: Jurnal Kajian Ilmu Hukum 3, no. 1 (1 June 2014): 24, http://ejournal.uin-suka.ac.id/syariah/Supremasi/article/view/1945.

${ }^{14}$ Myrna A. Safitri, 'Negara dan pluralisme hukum: Kebijakan pluralisme hukum di Indonesia pada masa kolonial dan masa kini', in Beragam Jalur Menuju Keadilan: Pluralisme Hukum dan Hak-hak Masyarakat Adat di Asia Tenggara, ed. Marcus Colchester and Sophie Chao (Jakarta: Epistema Institute, 2012), //perpustakaan.komnasham.go.id/opackomnas/index.php?p=show_detail\&id=11213\&keywords=.

${ }^{15}$ Sulistyowati Irianto, 'Pluralisme Hukum Dalam Perspektif Global', in Kajian Sosio-Legal, ed. Adriaan W. Bedner, Edisi pertama, Seri Unsur-Unsur Penyusun Bangunan Negara Hukum (Denpasar, Bali: Pustaka Larasan bekerja sama dengan Universitas Indonesia, Universitas Leiden, Universitas Groningen, 2012), 157.

${ }^{16}$ Azmi Fendri, 'Perbaikan Sistem Hukum Dalam Pembangunan Hukum Di Indonesia', Jurnal Ilmu Hukum 1, no. 2 (29 April 2013): 96, https://doi.org/10.30652/jih.v1i02.1157.
} 
research, does not exist. The posts are: Joeni Arianto Kurniawan ${ }^{17}$ He writes about Legal Pluralism and the Urgency of Socio-Legal Studies Towards a Just Study and Development of Law, according to him, legal development is not enough to just stand on legal justice alone, but also must reach social justice. Therefore, legal studies are not only about legal studies as taught by Kelsenian, but must also reach out to social issues. He emphasized the importance of socio-legal studies as an interdisciplinary study that combines dogmatic-legal studies with social studies.

Novi Dewi Masyithoh ${ }^{18}$, Dialectic of Legal Pluralism: Efforts to Solve Threats of Diversity and Religion in Indonesia. Legal-pluralism expected to be the best alternative in resolving SARA conflicts, using the Non-Penal approach. Imam Ropii, ${ }^{19}$ Respect for the Plurality of Public Law in the Frame of National Law as a Means of Strengthening National Integration. In substance, the constitution has guaranteed the existence of legal-pluralism. Therefore, recognition and appreciation of the plurality of laws is an appropriate instrument to confirm national integration. Legal-plurality is a very valuable social-capital and cultural. Nurul Zuriah, ${ }^{20}$ Multicultural Citizenship Education as a vehicle for legal education and constitutional awareness. Nurul explained that Multicultural citizenship education in higher education is a strategic and fundamental effort in the framework of civic education. Citizenship education plays a significant role as a vehicle for education and character transformation to build a nation that has legal awareness.

I Nyoman Putu Budiartha, ${ }^{21} \mathrm{He}$ explains that the pluralism-legal system influences the development of education, including legal education. It has also have influenced by Indonesian history. The new pattern of legal education in Indonesia can only lead people to legal compliance and obedience. He also emphasized that legal-education is not independent, but is related to social issues. Arief Budiono, ${ }^{22}$ Law Science as a Holistic Paradigm Perspective Science. He concluded that legal thinking is currently experiencing stagnation and doubted because it tends to be mainstream positivistic that encourages a paradigm shift in law science. Therefore, the holistic paradigm can be an alternative solution in learning law so that law becomes a real science. Dedy Sumardi, ${ }^{23}$ Islam, Legal Pluralism, and Reflections on a Homogeneous Society. Legal-pluralism does not arise from conflict but results from dialogue as an effort to harmonize the diversity of legal systems. It is an instrument for the formation of legal awareness of the community and the authorities to realize the

\footnotetext{
17 Joeni Arianto Kurniawan, 'Pluralisme Hukum Dan Urgensi Kajian Socio-Legal Menuju Studi Dan Pengembangan Hukum Yang Berkeadilan Sosial', Yuridika 27, no. 1 (2012), https://ejournal.unair.ac.id/YDK/article/view/284.

${ }_{18}$ Masyithoh, 'DIALEKTIKA PLURALISME HUKUM'.

${ }^{19}$ Imam Ropii, 'Penghormatan Pluralitas Hukum Masyarakat Dalam Bingkai Hukum Nasional Sebagai Sarana Meneguhkan Integrasi Bangsa', Jurnal Hukum Prasada 4, no. 1 (31 August 2017): 12-21, https://doi.org/10.22225/jhp.4.1.156.1-10.

${ }^{20}$ Nurul Zuriah, 'Pendidikan Kewarganegaraan Multikultural Sebagai Wahana Pendidikan Hukum Dan Kesadaran Berkonstitusi', Jurnal Wawasan Yuridika 23, no. 2 (28 October 2014): 207-22, https://doi.org/10.25072/jwy.v23i2.13.

${ }^{21}$ I. Nyoman Putu Budiartha, 'The Legal Pluralism in Law Education in Indonesia', Journal of Advanced Research in Law and Economics 11, no. 3 (15 June 2020): 771-74.

22 Arief Budiono and Wafda Vivid Izziyana, 'Ilmu Hukum Sebagai Keilmuan Perspektif Paradigma Holistik', Jurnal Hukum Novelty 9, no. 1 (28 February 2018): 89-99, https://doi.org/10.26555/novelty.v9i1.a6916.

${ }^{23}$ Sumardi, 'Islam, Pluralisme Hukum dan Refleksi Masyarakat Homogen'.
} 
concept of civil society. Sarip, ${ }^{24}$ Pluralism of the Vision of the State Law of Pancasila in the Mission of the Indonesian State Law. Plurality is the result of the historical record of the Indonesian rule of law. The law in Indonesia is based on Pancasila as the state philosophy is the vision of the state, and then state law is the mission used to achieve it based on the constitutional of Pancasila. Geoffrey Swenson, ${ }^{25}$ Legal Pluralism in Theory and Practice, this article proposes a new typological framework for conceptualizing legal-pluralism through four distinct archetypes- aggressive, competitive, and complementary - to help explain the relationship between state and non-state actors. He also outlined five main strategies used by domestic and international actors to influence relations between state and non-state justice systems: bridging, harmonizing, merging, subsidizing, and repression. And Bakti ${ }^{26}$ Legal Pluralism in The Dispute Settlement Mecanism of Natural Resource in Aceh. The development of legal-pluralism in Indonesia has begun to lead to the recognition and enforcement of customary law in national law. In the context of Aceh, the identification of customary law (Qanun) in which the state regulates the custom mechanism procedures and types of sanctions.

\section{Result and Discussion}

\section{The Urgency of Pluralism Education for Students}

Pluralism is a prerequisite for the establishment of civil society. ${ }^{27}$ Therefore, it should understand from the root by creating an order of life that respects and accepts diversity in the context of everyday life. ${ }^{28}$ Pluralism cannot be understood only by acknowledging and accepting the reality of a pluralistic society but must be accompanied by a sincere attitude to accept the fact that it is a gift from God. ${ }^{29}$ According to Nurcholis Madjid ${ }^{30}$ pluralism is also a necessity for the safety of humans. Pluralism is teaching that starts from the reality of how the diversity still life of a society is. ${ }^{31}$ It does not start from the assumption that every religion or culture is the same. Instead, it was born from the awareness of differences. In sociological theory, it explained that every difference, whatever its form, has the potential for conflict or unfair competition. ${ }^{32}$ When the dispute is unmanaged properly, is not compromised, or is not reconciled, there will be a conflict of

\footnotetext{
24 Sarip Sarip and Abdul Wahid, 'Kemajemukan Visi Negara Hukum Pancasila Dalam Misi Hukum Negara Indonesia', Refleksi Hukum: Jurnal Ilmu Hukum 2, no. 2 (14 September 2018): 109-24, https://doi.org/10.24246/jrh.2018.v2.i2.p109-124.

${ }^{25}$ Geoffrey Swenson, 'Legal Pluralism in Theory and Practice', International Studies Review 20, no. 3 (1 September 2018): 438-62, https://doi.org/10.1093/isr/vix060.

26 Baktu Bakti, 'Pluralisme Hukum dalam Mekanisme Penyelesaian Sengketa Sumber Daya Alam di Aceh', Kanun Jurnal Ilmu Hukum 17, no. 1 (1 April 2015): 129-49.

27 Farid Wajdi Ibrahim, 'Pembentukan Masyarakat Madani Di Indonesia Melalui Civic Education', JURNAL ILMIAH DIDAKTIKA: Media Ilmiah Pendidikan Dan Pengajaran 13, no. 1 (1 August 2012), https://doi.org/10.22373/jid.v13i1.469.

${ }^{28}$ M. Zainuddin, 'Urgensi Pendidikan Multikulturalisme', www.uin-malang.ac.id, accessed 27 December 2020, https://www.uin-malang.ac.id/blog/post/read/131101/urgensi-pendidikan-multikulturalisme.html.

${ }^{29}$ A. Ubaidillah et al., Demokrasi,hak asasi manusia dan masyarakat Madani (Jakarta: ICCE UIN Syarif Hidayatullah Jakarta, 2000), 117, //opac.fah.uinjkt.ac.id//index.php?p=show_detail\&id=797.

${ }^{30}$ Madjid, Islam.

${ }^{31}$ Ubaidillah et al., Demokrasi,hak asasi manusia dan masyarakat Madani.

${ }^{32}$ Muhammad Syawaludin, 'Memaknai Konflik Dalam Perspektif Sosiologi Melalui Pendekatan Konflik Fungsional', Tamaddun: Jurnal Kebudayaan dan Sastra Islam 14, no. 1 (2014): 1-18.
} 
interest, which does not rule out the possibility of causing a split. Because it is so dangerous if there is a conflict for human civilization, pluralism offers dialogue, mutual learning to understand each other. ${ }^{33}$ Law education to take an important role, because only through the path of this can the importance of integration be implanted by instilling an attitude of awareness of diversity, tolerance among citizens of different ethnicities, religions, nations, languages, and cultures, namely through integrated knowledge in the education system, ${ }^{34}$ where education is starting from primary, secondary, and higher education. If this education fails to instill pluralism, then the disintegration of the nation will inevitably occur. ${ }^{35}$

The issue of SARA (ethnicity, race, religion, and between groups) is a sexist issue and very easy to trigger conflict ${ }^{36}$ which can cause disruption of security and order. SARA conflict is one of the most vicious forms of violence, particularly the issue of religion, as stated by Clifford Geertz that religion is an adhesive element that can create cohesion, but at the same time is a divisive element that can lead to disintegration. ${ }^{37}$ Geertz's statement is in line with Parsudi Suparlan's assessment that ethnic solidarity often shifted to religious beliefs. Yunus ${ }^{38}$ gave an example of the Ambon conflict where the conflict turned into groups of Ambonese between Muslims and Christian. The number of casualties in the SARA conflict is more than the victims due to terrorism and war between countries. ${ }^{39}$

The issue of SARA is still a latent danger for national integration. Some examples can be cited, including the case of expulsion of Papuan students in Surabaya Saturday (17/8/2019) was the cause of riots in several areas in Papua and West Papua. ${ }^{40}$ And the issue is used as ammunition by the Free Papua Organization (OPM) to attack the government and inflame separatism. ${ }^{41}$ Another case of destroying mosques in Manado (29/12020), ${ }^{42}$ the vandalism of the Santo

\footnotetext{
${ }^{33}$ Umi Sumbulah and Nurjanah Nurjanah, Pluralisme agama: Makna dan lokalitas pola kerukunan antarumat beragama (Malang: UIN Maliki Press, 2013), vi, http://repository.uin-malang.ac.id/711/.

34 Yayah Khisbiyah and Atiqa Sabardila, Pendidikan Apresiasi Seni Wacana Dan Praktik Untuk Toleransi Pluralisme Budaya (Surakarta: Penerbit Pusat Studi Budaya dan Perubahan Sosial Universitas Muhammadiyah Surakarta, Kerjasama dengan Ford Foundation, 2004).

${ }^{35}$ Abdullah Abd Talib, 'Pluralisme Sebagai Keniscayaan Dalam Membangun Keharmonisan Bangsa', in FILSAFAT ISLAM: HISTORISITAS DAN AKTUALISASI (Peran dan Kontribusi Filsafat Islam bagi Bangsa), vol. Vol. 1 (Yogyakarta: FA Press, 2014), 61-78, http://digilib.uin-suka.ac.id/25530/.

${ }^{36}$ Masyithoh, 'DIALEKTIKA PLURALISME HUKUM'.

37 Clifford Geertz, 'Konflik Dan Integrasi Agama Dan Masyarakat Di Mojokuto', in Sejarah Dan Masyarakat: Lintasan Historis Islam Di Indonesia, ed. Taufik. Abdullah (Jakarta: Pustaka Firdaus, 1987), https://catalog.hathitrust.org/Record/000879822.

38 Firdaus M. Yunus, 'Konflik Agama di Indonesia Problem dan Solusi Pemecahannya', Substantia: Jurnal Ilmu-Ilmu Ushuluddin 16, no. 2 (12 October 2014): 217-28, https://doi.org/10.22373/substantia.v16i2.4930.

39 Setara Institute, 'Toleransi Keberagaman Semu', Setara Institute (blog), accessed 28 December 2020, https://setara-institute.org/toleransi-keberagaman-semu/.

40 'Ini Penyebab Kerusuhan di Wamena Papua, Berawal dari Kabar Hoaks di Sekolah Halaman all', KOMPAS.com, $\quad 28$ accessed December 2020, https://regional.kompas.com/read/2019/09/23/13330021/ini-penyebab-kerusuhan-di-wamena-papuaberawal-dari-kabar-hoaks-di-sekolah.

${ }^{41}$ Vincent Fabian Thomas, 'Moeldoko Tuding OPM Manfaatkan Kerusuhan Papua', tirto.id, accessed 28 December 2020, https://tirto.id/moeldoko-tuding-opm-manfaatkan-kerusuhan-papua-egPw.

${ }^{42}$ C. N. N. Indonesia, 'Kronologi Perusakan "Musala” Di Minahasa Utara Sulut', nasional, accessed 28 December 2020, https://www.cnnindonesia.com/nasional/20200131083812-12-470368/kronologiperusakan-musala-di-minahasa-utara-sulut.
} 
Yosep Parish Church in East Denpasar (9/7/2019), ${ }^{43}$ vandalism of Vihara and Temple in Tanjung Balai (29/7/2016), ${ }^{44}$ or a clash of a group of Menteng and Manggarai residents (21/4/2020) in Jakarta who never subsided even though social distancing of COVID 19 was on. ${ }^{45}$ What is no less worrying is that many young Muslim groups have been exposed to radicalism and have an intolerant attitude. ${ }^{46}$ As an agent of social changes, higher education institutions must be able to play a dominant role in educating students about legal-pluralism. As potential national leaders so that they have independent, intelligent, responsible thoughts, and become a pioneer for the development of tolerant and mature attitudes in responding to differences, and can develop values of pluralism as a foundation in the life of the nation and state. And the Faculty of Sharia and Law as part of the higher education system must also take an active role in disseminating the values of legal pluralism.

\section{Meaning of Legal Pluralism}

The definition of legal pluralism is well-defined as legal diversity, namely the presence of more than one legal rule in a social environment. ${ }^{47}$ Substantially, legal pluralism is well-defined as a situation in which two or more legal systems work side by side in the same field of social life, or to explain the existence of two or more social control systems in one area of social life. ${ }^{48}$ Legal pluralism is welldefined as a social reality. ${ }^{49}$ Each community group has its own legal system that differs from one another, such as in the family, age level, community, political group, which is a unitary homogeneous society. ${ }^{50}$ Hooker describes a situation in which two or more legal systems interact in one social life. ${ }^{51}$ In summary, you can say that legal pluralism is a reality in society lives. According to Brian Z. Tamanaha stated that legal pluralism is everywhere. ${ }^{52}$ Griffiths divides legal pluralism into two types are weak and sturdy pluralism of law. ${ }^{53}$ Weak Legal pluralism referred to the

\footnotetext{
43 Agung Sandi Lesmana, 'Perusak Gereja Katolik Denpasar Sempat Menangis dan Memeluk Salib', suara.com, 9 July 2019, https://jatim.suara.com/read/2019/07/09/163502/perusak-gereja-katolik-denpasarsempat-menangis-dan-memeluk-salib.

44 ‘Amuk masa di Tanjung Balai, vihara dan kelenteng dibakar', BBC News Indonesia, 30 July 2016, https://www.bbc.com/indonesia/berita_indonesia/2016/07/160730_indonesia_rusuh_tanjung_balai.

45 Kompas Cyber Media, 'Polisi Tangkap 5 Warga Menteng yang Terlibat Tawuran di Manggarai', KOMPAS.com, $\quad 28$ accessed December 2020, https://megapolitan.kompas.com/read/2020/04/23/15344111/polisi-tangkap-5-warga-menteng-yangterlibat-tawuran-di-manggarai.

46 Dirga Maulana, 'Transmisi Radikalisme Agama', Tempo, 1 June 2015, https://koran.tempo.co/read/opini/374230/transmisi-radikalisme-agama.

${ }^{47}$ Mujib, 'Memahami Pluralisme Hukum Di Tengah Tradisi Unifikasi Hukum', 24.

48 John Griffiths, 'What Is Legal Pluralism?', The Journal of Legal Pluralism and Unofficial Law 18, no. 24 (1 January 1986): 1-55, https://doi.org/10.1080/07329113.1986.10756387.

${ }^{49}$ Ropii, 'Penghormatan Pluralitas Hukum Masyarakat Dalam Bingkai Hukum Nasional Sebagai Sarana Meneguhkan Integrasi Bangsa'.

${ }^{50}$ Swenson, 'Legal Pluralism in Theory and Practice'.

${ }^{51}$ M. B. Hooker, Legal Pluralism: An Introduction to Colonial and Neo-Colonial Laws (Clarendon Press, 1975).

52 Brian Z. Tamanaha, 'Understanding Legal Pluralism: Past to Present, Local to Global', SSRN Scholarly Paper (Rochester, NY: Social Science Research Network, 3 September 2007), https://papers.ssrn.com/abstract=1010105.

53 Della Sri Wahyuni, 'Pluralisme Hukum Dalam Pembangunan Hukum Indonesia: Masalah Dan Tantangan Ke Depan', LEIP (blog), 16 November 2015, https://leip.or.id/pluralisme-hukum-dalampembangunan-hukum-indonesia-masalah-dan-tantangan-ke-depan-2/.
} 
state recognizes the presence of other elements of the legal system outside the state law, non-state legal are subject to their enforcement under state law. Meanwhile, sturdy legal pluralism exists when the state recognizes the existence of non-state law. The legal system has the same enforceability capacity as state law. In the early phase of its development, legal pluralism was understood as the co-existence between various legal systems in a particular social field under study, and strongly emphasized the dichotomy between one state law and another. ${ }^{54}$

That is, the experts only do a mapping of legal universe. ${ }^{55}$ But everything is changing, where the globalization era is accelerating this change. Laws from various levels and corners of the world are moving into borderless territories where there is strength contact, interaction, contestation, and mutual adoption between international, national, and local laws. ${ }^{56}$ Globalization is not only understood as a borderless state but also as borderless law, where it in certain areas can penetrate to other areas, without boundaries. ${ }^{57}$ From this meaning, we can understand that the study of legal pluralism is an important issue. In fact, according to M. Amin Abdullah, the legal pluralism needs to discuss amid the freezing of legal thought (Islam) in Indonesia. ${ }^{58}$

As a reality, the law is a science in motion. ${ }^{59}$ The movement is even faster in this era of globalization. There is a new paradigm in legal pluralism associated with laws moving in the realm of globalization. ${ }^{60}$ One example is in dispute resolution, there is alternative dispute resolution where the goal is to achieve a win-win solution. The mechanism of a community in solving problems can be emulated or borrowed by other local communities, which by Benda Beckmann, ${ }^{61}$ referred to as the borrowing modes of dispute resolution. Or Peace and Mediation in the Judiciary, for example, Indonesia emulates the concept of wakai and chotei from Japanese society. ${ }^{62}$ Or another example, the management of "lubuk larangan" (prohibition pond) by the Minangkabau indigenous community ${ }^{63}$ People agree to manage a river area, keep the fish that live within a possible time, and harvest it within a predetermined time and collectively, for the benefit of all. In managing lubuk larangan, customary law determines regarding management and penalties for violating the rules. In fact, the concept of lubuk larangan is now practiced not only in

\footnotetext{
${ }^{54}$ Griffiths, 'What Is Legal Pluralism?'

${ }^{55}$ Irianto, 'Pluralisme Hukum Dalam Perspektif Global'.

56 Wahyu Nugroho et al., 'Kebijakan Pengelolaan Tambang dan Masyarakat Hukum Adat yang Berkeadilan Ekologis', Jurnal Konstitusi 15, no. $4 \quad$ (15 January 2019): 816-35, https://doi.org/10.31078/jk1547.

${ }^{57}$ Irianto, 'Pluralisme Hukum Dalam Perspektif Global', 157.

58 Muhammad Amin Abdullah, 'Relevansi Studi Agama dalam Milenium Ketiga', in Mencari Islam: Studi Islam Dengan Berbagai Pendekatan, ed. Muhammad Amin Abdullah dkk (Yogya: Tiara Wacana, 2000).

${ }^{59}$ Budiono and Izziyana, 'Ilmu Hukum Sebagai Keilmuan Perspektif Paradigma Holistik'.

${ }^{60}$ Irianto, 'Pluralisme Hukum Dalam Perspektif Global'.

${ }^{61}$ Franz von Benda-Beckmann, Keebet von Benda-Beckmann, and Anne M. O. Griffiths, Mobile People, Mobile Law: Expanding Legal Relations in a Contracting World (Ashgate, 2005).

${ }^{62}$ Ahmad Mujahidin, Ruang Lingkup Dan Praktek Mediasi Sengketa Ekonomi Syariah (Yogyakarta: CV Budi Utama, 2018).

${ }^{63}$ Amin Pawarti, 'Pelestarian Lingkungan Melalui Kearifan Lokal Lubuk Larangan Ngalau Agung (Studi Di Kampuang Surau Nagari Gunung Selasih Kecamatan Pulau Punjung Kabupaten Dharmasraya Provinsi Sumatera Barat)' (masters, Program Magister Ilmu Lingkungan Undip, 2012), http://eprints.undip.ac.id/37843/.
} 
the Minangkabau community but also outside of Minangkabau, such as Jambi, ${ }^{64}$ Riau $^{65}$ dan North Sumatera, khususnya Mandailing Natal. ${ }^{66}$

Pluralism is a form of forming a harmonious diversity of society, ${ }^{67}$ because legal pluralism is not a new concept that has emerged in a modern legal system, but an approach to analyzing the operation of various legal systems side by side in the legal-system used in a government. ${ }^{68}$ Legal pluralism arises from a pluralistic society and interacts with one another according to their identity. It is because every person is not born from a single value system (mono value), but come from various value systems in the form of religion, culture, custom, ethnicity, or race. ${ }^{69}$ This diversity is not something that must be avoided, or enforced in a legal framework known as legal centralism. ${ }^{70}$ It is carried out by state law in the legal system competes with each other by making a positivistic paradigm so that it provides an assessment of human behavior as a legal-object. ${ }^{71}$ The consequence of the centralistic system has an impact on the emergence of the centralistic nature of law. ${ }^{72}$ That is, it centered on the interests of the ruler. In specific cases, they often ignore the value system that develops in a pluralistic society. ${ }^{73}$ The value system contained in every community becomes a social binder and drives economic and social life through the principle of reciprocity and principle of publicity ${ }^{74}$ that has been going on together. Diversity of value systems can be managed well through the perspective of it, without forgetting fundamental values as part of community identity. This last perspective positions humans as legal subjects and interacts with one another. ${ }^{75}$

\footnotetext{
${ }^{64}$ Mohammad Faisal, Mohammad Gamal Rindarjono, and Chatarina Muryani, 'Analisis Lubuk Larangan Sebagai Wisata Ekologi Berbasiskan Kearifan Lokal Desa Lubuk Beringin, Kecamatan Bathin Iii Ulu, Bungo, Jambi (Sebagai Pendukung Substansi Materi Pengelolaan Sumber Daya Alam Pada Bidang Studi Geografi Di Kelas Xi Sma)', GeoEco 2, no. 2 (11 July 2016), https://jurnal.uns.ac.id/GeoEco/article/view/8922.

65 Agustinus Wijayanto, 'Ternyata Ada Lubuk Larangan Di Sungai Subayang, Seperti Apa?', Mongabay Environmental News, 27 September 2018, https://www.mongabay.co.id/2018/09/27/ternyata-ada-lubuklarangan-di-sungai-subayang-seperti-apa/.

66 Zulkifli B Lubis, 'Community-Based River Conservation: Reviving of the Natural Sacred Sites in Mandailing Natal Regency', in Situs Keramat Alami: Peran Budaya Dalam Konservasi Keanekaragaman Hayati, ed. Herwasono Soedjito (Jakarta: Yayasan Pustaka Obor Indonesia, 2009), x.

${ }^{67}$ Mohammad Fahrur Rozi, 'Pluralisme Dan Multikulturalisme Dalam Membangun Masyarakat Madani; Kajian Paradigmatik', AL - IBRAH 2, no. 2 (31 December 2017): 104-27.

${ }^{68}$ Kunjana, 'Pluralisme Hukum Wujud Harmonisasi Keberagaman'.

${ }^{69}$ Sumardi, 'Islam, Pluralisme Hukum dan Refleksi Masyarakat Homogen', 482.

70 Berihun Adugna Gebeye, 'Legal Theory in Africa: Between Legal Centralism and Legal Pluralism', SSRN Scholarly Paper (Rochester, NY: Social Science Research Network, 4 July 2017), https://papers.ssrn.com/abstract=2991040.

${ }^{71}$ Neni Sri Imaniyati, 'Pengaruh Paradigma Positivisme Terhadap Teori Hukum dan Perkembangannya', MIMBAR: Jurnal Sosial dan Pembangunan 19, no. 3 (13 September 2003): 261-77, https://doi.org/10.29313/mimbar.v19i3.108.

72 Septi Nur Wijayanti, 'Hubungan Antara Pusat dan Daerah Dalam Negara Kesatuan Republik Indonesia Berdasarkan Undang-Undang Nomor 23 Tahun 2014', Jurnal Media Hukum 23, no. 2 (2016): 186-99, https://doi.org/10.18196/jmh.2016.0079.186-199.

${ }^{73}$ Boedhi Oetojo, Pluralisme, Sistem Sosial Budaya Indonesia (Jakarta: Universitas Terbuka, 2016).

74 Yusnita Eva, 'Perspektif Dan Kajian Hukum Dari Beberapa Tokoh Dalam Bidang Antropologi Hukum', Mimbar Hukum - Fakultas Hukum Universitas Gadjah Mada 22, no. 1 (2010): 170-87, https://doi.org/10.22146/jmh.16213.

75 Wahyuni, 'Pluralisme Hukum Dalam Pembangunan Hukum Indonesia'.
} 
Plurality itself is a characteristic of Indonesia. ${ }^{76}$ With many islands, ethnicities, nations, religions, languages, and cultures, Indonesia wants to build a stable and modern state with strong national ties. According to Erman Rajagukguk, avoiding pluralism is tantamount to avoid different realities regarding the perspectives and beliefs that live in Indonesian society. ${ }^{77}$ The positivistic or legalistic approach is the only legal reference in the mechanism for solving legal problems in the court. It has ignored the facts and history of community lives. There are various kinds of laws, ${ }^{78}$ namely: customary law, religious law, and community customs. They do not even rule out the implementation of international law. It involves parties from other countries, ${ }^{79}$ According to Simarmata, ${ }^{80}$ the development of legal pluralism has begun to lead to the phenomenon of transnational law, such as laws produced by multilateral and bilateral organizations and international financial institutions, along with their interdependent relationships with national and local laws. Simarmata's statement is supported by Benda Beckmann, who states that the Act is a broad normative reference that continues to live and develop dynamically, including not only state law, but also norm systems outside the state, plus all processes and actors. Law does not just contain normative conceptions: things that are prohibited and permitted but also contain cognitive concepts. ${ }^{81}$ This concept is called "Mobile People Mobile Law", which illustrates the existence of a chain of interactions that connects transnational, national, and local actors who carry out negotiations in a multi-sited arena and based on power relations. ${ }^{82}$ Legal pluralism has perhaps become one of the most attractive and most controversial terms in the literature on legal theory, legal anthropology, and legal sociology. ${ }^{83}$ According to Tammanaha, as quoted by Simarmata ${ }^{84}$ So far, the term legal pluralism has been considered a key concept in post-modern legal studies. Legal pluralism is very helpful in explaining the fact that there is a legal-order produced by the state. Meanwhile, according to Griffiths, ${ }^{85}$ the situation of legal pluralism is growing along with the pace of social pluralism. Therefore, it is showed that a plural society gives birth to a plural legal system. On the other hand, the imposition of legal centralism is futile work because it is asocial in nature. ${ }^{86}$

\section{Implementation of Legal Pluralism in the Context of State Law}

Some several laws and regulations reflect the state's success in implementing legal pluralism, but some are still failing. One example of the successful

\footnotetext{
${ }^{76}$ Madjid, Islam.

77 'Pluralisme Hukum Harus Diakui', hukumonline.com, 2 July 2006, https://www.hukumonline.com/berita/baca/hol15089/pluralisme-hukum-harus-diakui/.

78 Mukhidin, 'Hukum Progresif Sebagai Solusi Hukum Yang Mensejahterakan Rakyat', Jurnal Pembaharuan Hukum 1, no. 3 (2014): 267.

79 Bakti, 'Pluralisme Hukum dalam Mekanisme Penyelesaian Sengketa Sumber Daya Alam di Aceh', 129-49.

${ }^{80}$ Ricardo Simarmata, Mencari Karakter Aksional Dalam Pluralisme Hukum (Jakarta: Huma Press, 2005), 7.

${ }^{81}$ Benda-Beckmann, Benda-Beckmann, and Griffiths, Mobile People, Mobile Law, ix.

82 Benda-Beckmann, Benda-Beckmann, and Griffiths, 9.

83 Bakti:

${ }^{84}$ Simarmata, Mencari Karakter Aksional Dalam Pluralisme Hukum, 3.

${ }^{85}$ Griffiths, 'What Is Legal Pluralism?'

${ }^{86}$ Bakti, 'Pluralisme Hukum dalam Mekanisme Penyelesaian Sengketa Sumber Daya Alam di Aceh'.
} 
implementation of legal pluralism is the rise of regional sharia regulations, qanuns in Aceh, ${ }^{87}$ and the establishment of customary institutions recognized as media for settling traditional disputes, such as the formation of adat assemblies and councils of Dayak in Kalimantan. ${ }^{88}$ And West Sumatra Regional Regulation Number 7 of 2018 concerning Nagari.

Meanwhile, examples that show the failure of the government in implementing legal pluralism are the existing conflict between customary law and state law. Act No. 5 of 1960 (Basic Agrarian Act) recognizes the rights of traditional communities in control of land and natural resources, but added regulations negate this principle, in the Forestry Act (Act No. 41 of 1999). For example, identify the existence of customary forests. However, the law places customary forests as part of state forests. These legal system conflicts often lead to horizontal or vertical conflicts and illustrate that there is a gap between lawmakers (state institutions) and law enforcers (society). ${ }^{89}$ Such conflicts sometimes also become the cause of barren state law in the implementation order. It seems to emphasize that the emergence of rejection of state law is not just a matter of limited understanding or unawareness of public law, more than that is due to the people's unwillingness to obey laws that are different from their daily lives. ${ }^{90}$

\section{Change of Degree and the Urgency of Legal Pluralism Learning in the Faculty of Sharia and Law}

In mid of 2016, the Minister of Religion issued Regulation of the Minister of Religion (PMA) No. 33 of 2016 concerning Academic Degrees in Religious Colleges. This regulation replaces the Minister of Religion Regulation No. 36 of 2009 concerning the Determination of Fields of Science and Academic Degrees in Religious Colleges. With the birth of PMA No. 33 of 2016, the degree of Bachelor of Syari'ah (S.Sy) or Bachelor of Islamic Law (S.HI) that is usually held by graduates of the Sharia Faculty has officially changed to Bachelor of Law (SH). On the one hand, the publication of PMA No. 33 of 2016 should warmly because graduates of the Sharia and Law Faculty are equivalent to graduates of the Law Faculty of public universities. With this degree equivalence, it hoped that the field of work that the alumnus of the Faculty of Sharia and Law will undertake is more wide open. In the profession of lawyers, for example, Sharia and Law graduates are no longer limited to handling cases with religious nuances such as family cases, sharia economics. They are open to other fields such as criminal, civil, state administration, civil cases. Likewise, other legal professions, it is not impossible to be occupied by sharia graduates such as prosecutors, judges at general courts, state administrative judges, and judges at commercial courts. Another hope is, because when college equipped with sufficient religious knowledge.

But on the other hand, what needs to consider is that the change in the title for the Sharia Faculty is only in the "change of exchange" order, substantially, there

\footnotetext{
87 The basic legal for the formation of the Qanun in Aceh is Law no. 18 of 2001 concerning the Government of Aceh. Through the special autonomy system in effect in Aceh, the Aceh Regional Government has integrated sharia (Islamic) law and customary law in the Qanun.

${ }^{88}$ For example, the formation of indigenous Dayak assemblies and councils in Kalimantan.

${ }^{89}$ Wahyuni, 'Pluralisme Hukum Dalam Pembangunan Hukum Indonesia'.

${ }^{90}$ Safitri, 'Negara dan pluralisme hukum: Kebijakan pluralisme hukum di Indonesia pada masa kolonial dan masa kini'.
} 
has been no change that has led to the birth of faculty alumni who "deserve" a law degree and are able to compete with other laws scholars. Because changing undergraduate degrees has happened several times, from Doktorandus, to Bachelor of Religion, then Bachelor of Sharia, then to Bachelor of Islamic Law and now Bachelor of Law. What the author needs to emphasize here is that changes to the degree must follow up with significant, systematic and planned changes in order to produce superior and reliable graduates in the field of law, so that this hope will come true.

Sharia and law faculty graduates hold a law degree, one of the professional fields that can attain is being a judge. As the executor of judicial power, judges must be able to carry out ijtihad independently and free from intervention from anywhere. ${ }^{91}$ In the Constitution 1945, Article 24 paragraph (1) it is emphasized that: independent judicial power to administer justice in order to uphold law and justice. To carry out the constitutional mandate in upholding the law and justice, Law no. 14 of 1970 jo. Article 27 paragraph (1), Junto Law no. 35 of 1999 concerning Judicial Power states that judges in making their decisions must pay attention to the values that live in society. From the explanation of Article 27 paragraph (1) of Law No. 14 of 1970 states: in a society that is still familiar with an unwritten law, and is in a period of upheaval and transition. Judges are formators and diggers of law values that live in the community. For that, he must go into the midst of society to get to know, feel, and be able to understand the feelings of law and the sense of justice that lives in society. Thus the judge can decide under the law and fairness of the community. His decision is following the law and the sense of justice of society. The judge is not a mouthpiece for the Act. The judge is the mouthpiece of fairness, decency, public interest, and public order. ${ }^{92}$

In the legal system of Indonesia, the law is not the only source of law, the adat law is also a source of law. Thus, judges must be able to use customs, laws that live in the community as legal references. Law graduates cannot know, understand, and make references to the Act that are lived in the society if the judges have never studied customary law, sociology and legal anthropology, socio-legal, or legal pluralism in Indonesia. However, it must remember that legal pluralism does not immediately solve problems that arise in society. However, legal pluralism exists to provide a new understanding to legal practitioners, state lawmakers (legislators), and people at large. The legal system interacts with state law and even compete with each other. ${ }^{93}$

\section{Implementation of Legal Prulalism Teaching in the Faculty of Sharia and Law}

At the Faculty of Law, University of Indonesia, in general, Legal Pluralism taught integrated into several subjects, including legal anthropology, legal sociology, law, and society. However, the methodology of the law faculty has a course in the Legal Research Methods of Socio-legal Studies, which is a method

\footnotetext{
91 Bagir Manan, Menegakkan hukum, suatu pencarian (Jakarta: Ikatan Advokat Indonesia, 2009); Evi Ariyani and Luthfiana Zahriani, Hukum dan wajah hakim dalam dinamika hukum acara peradilan (Surakarta: Iltizam Press, 2016), 15.

92 Budi Suhariyanto, 'Eksistensi Pembentukan Hukum Oleh Hakim Dalam Dinamika Politik Legislasi Di Indonesia', Jurnal Rechts Vinding: Media Pembinaan Hukum Nasional 4, no. 3 (31 December 2015): 413, https://doi.org/10.33331/rechtsvinding.v4i3.14.

${ }^{93}$ Wahyuni, 'Pluralisme Hukum Dalam Pembangunan Hukum Indonesia'.
} 
that teaches how to conduct socio-legal research (Dyah, interview) ${ }^{94}$ The Sharia and Law Faculty can do the same thing. Based on the author's experience, the issue of legal pluralism can be inserted in the subjects of Civic Education, Tarikh Tasyri, Legal Anthropology, and Research Methods, where the author gave the mandate to teach them. And integration takes place in two forms. The first is in a Hypothetical view where the content of legal pluralism issues can be discussed and reviewed in sub-discussion of material in the subjects: Civic Education, Tarik Tasyri, and Legal Anthropology. And the second is applied view, where legal pluralism is teaching in the Legal Research method course.

In the subject of legal anthropology, for example, discussing legal pluralism is associated with socio-legal issues, especially the introduction of customary law. The approach used by the author is: stay, touch, and feel. The expectation of it can be an alternative strategy for implementing legal pluralism. There are two approaches, namely formal-theoretical and informal-empiric. The learning objectives of both are the customary laws that apply in an indigenous group. The object learning is cultivating a sense of tolerance, teaching openness (open-mindedness), fostering a desire to continue to feel curious (curiosity) towards other groups, formal-theoretical by teaching about legal pluralism, including therein customary law. Whereas informal-empiric is executed by living with a community, for several days, hang out with them, observe, do, and experience some activities with them. The results of these observations are then made a report in the form of a short movie. This short movie published through the YouTube channel so that it can be seen and known to the broader community. Only the community groups where students interact learning about the living law, namely the Baduy Community ${ }^{95}$ and the Kepulauan Seribu Community. ${ }^{96}$ The author believes that introducing other groups in this way is the basis for achieving tolerance and appreciation for other groups that can develop it into the ability to live together harmoniously and creatively. Besides teaching awareness of historical continuity, strengthening historical and cultural awareness is a provision for the formation of a national self-identity.

Whereas in applied view, the writer also tries to insert the material of LegalPluralism in the law teaching of Legal Research Methods, although in a very limited portion. Legal pluralism is used as an approach that needs to be introduced to students of the Faculty of Sharia and law in legal research methods so that research in the Sharia and law families is more humanist and able to represent people's anxiety. ${ }^{97}$ In another sense, an understanding of legal pluralism will be able to solve the awkwardness in Sharia and legal thinking in Indonesia. Nevertheless, such an approach is also not devoid of harsh criticism from legal experts, such as

\footnotetext{
${ }^{94}$ Dyah Wirastri, Interview (Jakarta, 1 June 2020).

95 Ahmad Farhan Hadad, Ekspedisi Baduy - Sistem Ketatanegaraan Baduy [Ilmu Hukum UIN Jakarta], 2019, https://www.youtube.com/watch?v=hTP9KRJLquc\&t=464s\%2C; Bayu Hidayat, Mengenal Hukum Pidana Di Baduy, 2019, https://www.youtube.com/watch?v=2V32aEnE0j0\&t=340s; Almira Mey Theda, Masyarakat Baduy Anti Poligami? WOW $\square$, , 2019, https://www.youtube.com/watch?v=DyPpTD_Wucs. 96 suddenlyproject, EKSPEDISI PULAU SABIRA: Konservasi Penyu \& Hasil Laut, 2019, https://www.youtube.com/watch?v=U82ZqyrfDKA\&t=186s; Ashiilah Nur Firyaal, What Happened in Tidung Island?, 2019, https://www.youtube.com/watch?v=hnisoNaZX_o; Wahyu Istiham, Restorative Justice Kepulauan Rakitiang Kelapa 2019, https://www.youtube.com/watch?v=auN1X4Vzp68.

${ }^{97}$ Muhammad Amin Abdullah, 'Relevansi Studi Agama dalam Milenium Ketiga'.
} 
that of Peter Mahmud Marzuki, that considers that legal research with a non-legal approach will pollute law science. This effort is considered entirely unproductive for the development of law science in general and for the preparation of the legal profession that prospective law graduates must undertake. In other words, the existence of such research does not make the law faculty become a faculty for potential practitioners or professionals. And this causes law faculties in Indonesia to lag behind law faculties in other countries. ${ }^{98}$ This opinion can negate by arguing that in fact law cannot be understood only through the text or legal dogma alone. Do we have to find an answer to why a legal contains a positive philosophy? Is a law fair to a group of people? Or how can the judge make a decision that must be "pay attention to the values that live in a society " as referred to Article 27 paragraph (1), Junto Law no. 35 of 1999 concerning Judicial Power? We can never know unless we go down to society, see and learn it through observation, or do in-depth interviews with people.

The Faculty of Sharia and Law is also required to improve the soft skills of prospective alumni in the field of legal skills through activities carried out by the Law Laboratory. One of them is legal advocacy for the community. In this program. The concept of legal pluralism can be useful for efforts to build a just law for the most marginalized groups in the socio-political process in this country. Legal pluralism is also ammunition to fight for community rights to land and natural resources. Another activity is that the Faculty of Sharia and Law can contribute to legal thinking for both the government and the legislature by submitting proposals for Academic Papers of laws that will be discussing. For example, in the discussion of amendments to the Criminal Code, Civil Code, and other relevant laws, they require the inclusion of elements of sharia in them, legal research using legal pluralism analysis knife will help provide clarity and clearer legal considerations and based on empirical facts as the law that lives in the society and is practiced by the Indonesian people.

\section{Conclusion}

Legal pluralism is a significant material to be taught to Sharia and law faculty students with the aim not only to know and understand the diversity of laws, especially laws in Indonesia but beyond that, namely to grow awareness and create an attitude that respects and accepts diversity law. Given the change in academic degrees for Islamic legal faculties under the Regulation of the Minister of Religion (PMA) No. 33 of 2016 concerning Higher Education Academic Degrees, it possible for the Islamic law scholar to understand the legal values that live in society and can use it as a legal reference. The implementation of legal pluralism teaching can be done through independent courses or integrated into other possible courses in both hypothetical view and applied view.

\footnotetext{
98 Peter Mahmud Marzuki, Penelitian hukum (Jakarta: Kencana, 2007), http://opac.library.um.ac.id/oaipmh/../index.php?s_data=bp_buku\&s_field=0\&mod=b\&cat=3\&id=34357; Titon Slamet Kurnia, Sri Harini Dwiyatmi, and Dyah Hapsari Prananingrum, Pendidikan hukum, ilmu hukum \& penelitian hukum di Indonesia: sebuah reorientasi (Yogyakarta: Pustaka Pelajar, 2013).
} 


\section{Bibilography}

Abd Talib, Abdullah. 'Pluralisme Sebagai Keniscayaan Dalam Membangun Keharmonisan Bangsa'. In FILSAFAT ISLAM: HISTORISITAS DAN AKTUALISASI (Peran dan Kontribusi Filsafat Islam bagi Bangsa), Vol. 1:61-78. Yogyakarta: FA Press, 2014. http://digilib.uin-suka.ac.id/25530/.

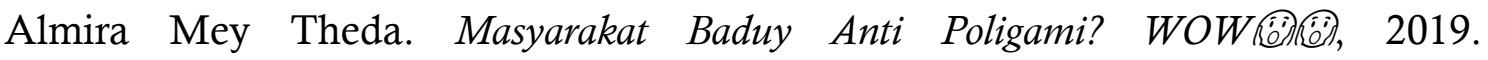
https://www.youtube.com/watch?v=DyPpTD_Wucs.

BBC News Indonesia. 'Amuk masa di Tanjung Balai, vihara dan kelenteng dibakar', $\quad 30 \quad$ July 2016. https://www.bbc.com/indonesia/berita_indonesia/2016/07/160730_indon esia_rusuh_tanjung_balai.

Ariyani, Evi, and Luthfiana Zahriani. Hukum dan wajah hakim dalam dinamika hukum acara peradilan. Surakarta: Iltizam Press, 2016.

Ashiilah Nur Firyaal. What Happened in Tidung Island?, 2019. https://www.youtube.com/watch?v=hnisoNaZX_o.

Badan Pusat Statistik. 'Sensus Pendduk Indonesia'. Accessed 27 December 2020. https://www.bps.go.id/indikator/indikator/view_data_pub/0000/api_pub /50/da_03/1.

Bakti, Baktu. 'Pluralisme Hukum dalam Mekanisme Penyelesaian Sengketa Sumber Daya Alam di Aceh'. Kanun Jurnal Ilmu Hukum 17, no. 1 (1 April 2015): 129-49.

Benda-Beckmann, Franz von, Keebet von Benda-Beckmann, and Anne M. O. Griffiths. Mobile People, Mobile Law: Expanding Legal Relations in a Contracting World. Ashgate, 2005.

Budiartha, I. Nyoman Putu. 'The Legal Pluralism in Law Education in Indonesia'. Journal of Advanced Research in Law and Economics 11, no. 3 (15 June 2020): 771-774-771-74.

Budiono, Arief, and Wafda Vivid Izziyana. 'Ilmu Hukum Sebagai Keilmuan Perspektif Paradigma Holistik'. Jurnal Hukum Novelty 9, no. 1 (28 February 2018): 89-99. https://doi.org/10.26555/novelty.v9i1.a6916.

IBTimes.ID. 'Data Populasi Penduduk Muslim 2020: Indonesia Terbesar di Dunia', 8 April 2020. https://ibtimes.id/data-populasi-penduduk-muslim2020-indonesia-terbesar-di-dunia/.

Eva, Yusnita. 'Perspektif Dan Kajian Hukum Dari Beberapa Tokoh Dalam Bidang Antropologi Hukum'. Mimbar Hukum - Fakultas Hukum Universitas Gadjah Mada 22, no. 1 (2010): 170-87. https://doi.org/10.22146/jmh.16213.

Faisal, Mohammad, Mohammad Gamal Rindarjono, and Chatarina Muryani. 'Analisis Lubuk Larangan Sebagai Wisata Ekologi Berbasiskan Kearifan Lokal Desa Lubuk Beringin, Kecamatan Bathin Iii Ulu, Bungo, Jambi (Sebagai Pendukung Substansi Materi Pengelolaan Sumber Daya Alam Pada Bidang Studi Geografi Di Kelas Xi Sma)'. GeoEco 2, no. 2 (11 July 2016). https://jurnal.uns.ac.id/GeoEco/article/view/8922.

Fendri, Azmi. 'Perbaikan Sistem Hukum Dalam Pembangunan Hukum Di Indonesia'. Jurnal Ilmu Hukum 1, no. 2 (29 April 2013). https://doi.org/10.30652/jih.v1i02.1157. 
Gebeye, Berihun Adugna. 'Legal Theory in Africa: Between Legal Centralism and Legal Pluralism'. SSRN Scholarly Paper. Rochester, NY: Social Science Research Network, 4 July 2017. https://papers.ssrn.com/abstract=2991040.

Geertz, Clifford. 'Konflik Dan Integrasi Agama Dan Masyarakat Di Mojokuto'. In Sejarah Dan Masyarakat: Lintasan Historis Islam Di Indonesia, edited by Taufik. Abdullah. Jakarta: Pustaka 1987. https://catalog.hathitrust.org/Record/000879822.

Griffiths, John. 'What Is Legal Pluralism?' The Journal of Legal Pluralism and Unofficial Law 18, no. 24 (1 January 1986): 1-55. https://doi.org/10.1080/07329113.1986.10756387.

Hadad, Ahmad Farhan. Ekspedisi Baduy - Sistem Ketatanegaraan Baduy [Ilmu Hukum UIN Jakarta], 2019. https://www.youtube.com/watch?v=hTP9KRJLquc\&t=464s\%2C.

Hiariej, Eddy O.S. 'Pembaharuan Hukum Publik Dan Hukum Privat'. In Memperkuat Peradaban Hukum Dan Ketatanegaraan Indonesia, edited by Imron and Festy Rahma Hidayati. Jakarta: Sekretaris Jenderal Komisi Yudisial, 2019.

Hidayat, Bayu. Mengenal Hukum Pidana Di Baduy, 2019. https://www.youtube.com/watch?v=2V32aEnE0j0\&t=340s.

Hooker, M. B. Legal Pluralism: An Introduction to Colonial and Neo-Colonial Laws. Clarendon Press, 1975.

Ibrahim, Farid Wajdi. 'Pembentukan Masyarakat Madani Di Indonesia Melalui Civic Education'. JURNAL ILMIAH DIDAKTIKA: Media Ilmiah Pendidikan Dan Pengajaran 13, no. 1 (1 August 2012). https://doi.org/10.22373/jid.v13i1.469.

Imaniyati, Neni Sri. 'Pengaruh Paradigma Positivisme Terhadap Teori Hukum dan Perkembangannya'. MIMBAR: Jurnal Sosial dan Pembangunan 19, no. 3 (13 September 2003): 261-77. https://doi.org/10.29313/mimbar.v19i3.108.

Indonesia, C. N. N. 'Kronologi Perusakan "Musala" Di Minahasa Utara Sulut'. nasional. $\quad$ Accessed 28 December 2020. https://www.cnnindonesia.com/nasional/20200131083812-12470368/kronologi-perusakan-musala-di-minahasa-utara-sulut.

KOMPAS.com. 'Ini Penyebab Kerusuhan di Wamena Papua, Berawal dari Kabar Hoaks di Sekolah Halaman all'. Accessed 28 December 2020. https://regional.kompas.com/read/2019/09/23/13330021/ini-penyebabkerusuhan-di-wamena-papua-berawal-dari-kabar-hoaks-di-sekolah.

Institute, Setara. 'Toleransi Keberagaman Semu'. Setara Institute (blog). Accessed 28 December 2020. https://setara-institute.org/toleransi-keberagaman-semu/.

Irianto, Sulistyowati. 'Pluralisme Hukum Dalam Perspektif Global'. In Kajian Sosio-Legal, edited by Adriaan W. Bedner, Edisi pertama. Seri Unsur-Unsur Penyusun Bangunan Negara Hukum. Denpasar, Bali: Pustaka Larasan bekerja sama dengan Universitas Indonesia, Universitas Leiden, Universitas Groningen, 2012.

Istiham, Wahyu. Restorative Justice Kepulauan Rakitiang (Pulau Kelapa Dua), 2019. https://www.youtube.com/watch?v=auN1X4Vzp68.

Kherid, Muhammad Nizar, and Fifiana Wisnaeni. 'Pluralism Justice System Dalam Penyelesaian Masalah Kebebasan Beragama'. Masalah-Masalah 
172 | De Jure: Jurnal Hukum dan Syar'iah, Vol. 12 No. 2 Tahun 2020

Hukum 48, no. 4 (16 October 2019): 385-392-392. https://doi.org/10.14710/mmh.48.4.2019.385-392.

Khisbiyah, Yayah, and Atiqa Sabardila. Pendidikan Apresiasi Seni Wacana Dan Praktik Untuk Toleransi Pluralisme Budaya. Surakarta: Penerbit Pusat Studi Budaya dan Perubahan Sosial Universitas Muhammadiyah Surakarta, Kerjasama dengan Ford Foundation, 2004.

Kunjana, Gora. 'Pluralisme Hukum Wujud Harmonisasi Keberagaman'. investor.id. $\quad$ Accessed 27 December 2020. https://investor.id/archive/pluralisme-hukum-wujud-harmonisasikeberagaman.

Kurnia, Titon Slamet, Sri Harini Dwiyatmi, and Dyah Hapsari Prananingrum. Pendidikan hukum, ilmu hukum \& penelitian hukum di Indonesia: sebuah reorientasi. Yogyakarta: Pustaka Pelajar, 2013.

Kurniawan, Joeni Arianto. 'Pluralisme Hukum Dan Urgensi Kajian Socio-Legal Menuju Studi Dan Pengembangan Hukum Yang Berkeadilan Sosial'. $\begin{array}{lllll}\text { Yuridika 27, no. } & 1 & \text { (2012). } & \text { https://e- }\end{array}$ journal.unair.ac.id/YDK/article/view/284.

Lesmana, Agung Sandi. 'Perusak Gereja Katolik Denpasar Sempat Menangis dan Memeluk Salib'. Suara.com, 9 July 2019. https://jatim.suara.com/read/2019/07/09/163502/perusak-gereja-katolikdenpasar-sempat-menangis-dan-memeluk-salib.

Lubis, Zulkifli B. 'Community-Based River Conservation: Reviving of the Natural Sacred Sites in Mandailing Natal Regency'. In Situs Keramat Alami: Peran Budaya Dalam Konservasi Keanekaragaman Hayati, edited by Herwasono Soedjito. Jakarta: Yayasan Pustaka Obor Indonesia, 2009.

Madjid, Nurcholish. Islam: Doktrin \& Peradaban. Jakarta: Gramedia Pustaka Utama, 2019.

Manan, Bagir. Menegakkan hukum, suatu pencarian. Jakarta: Ikatan Advokat Indonesia, 2009.

Marzuki, Peter Mahmud. Penelitian hukum. Jakarta: Kencana, 2007. http://opac.library.um.ac.id/oaipmh/../index.php?s_data=bp_buku\&s_fiel $\mathrm{d}=0$ \& $\bmod =\mathrm{b} \& \mathrm{cat}=3 \& \mathrm{id}=34357$.

Maslul, Syaifullahil and Ahmad Arif. 'Hukum Islam dan Politik Hukumnya dalam Hukum Nasional'. Al-Bayyinah 3, no. 1 (31 July 2019): 15-27.

Masyithoh, Novita Dewi. 'DIALEKTIKA PLURALISME HUKUM: Upaya Penyelesaian Masalah Ancaman Keberagaman dan Keberagamaan di Indonesia'. Walisongo: Jurnal Penelitian Sosial Keagamaan 24, no. 2 (15 December 2016): 359-78. https://doi.org/10.21580/ws.24.2.1289.

Maulana, Dirga. 'Transmisi Radikalisme Agama'. Tempo, 1 June 2015. https://koran.tempo.co/read/opini/374230/transmisi-radikalisme-agama.

Media, Kompas Cyber. 'Polisi Tangkap 5 Warga Menteng yang Terlibat Tawuran di Manggarai'. KOMPAS.com. Accessed 28 December 2020. https://megapolitan.kompas.com/read/2020/04/23/15344111/polisitangkap-5-warga-menteng-yang-terlibat-tawuran-di-manggarai.

Muhammad Amin Abdullah. 'Relevansi Studi Agama dalam Milenium Ketiga'. In Mencari Islam: Studi Islam Dengan Berbagai Pendekatan, edited by Muhammad Amin Abdullah dkk. Yogya: Tiara Wacana, 2000. 
Mujahidin, Ahmad. Ruang Lingkup Dan Praktek Mediasi Sengketa Ekonomi Syariah. Yogyakarta: CV Budi Utama, 2018.

Mujib, M. Misbahul. 'Memahami Pluralisme Hukum Di Tengah Tradisi Unifikasi Hukum: Studi Atas Mekanisme Perceraian Adat'. Supremasi Hukum: Jurnal Kajian Ilmu Hukum 3, no. 1 (1 June 2014). http://ejournal.uinsuka.ac.id/syariah/Supremasi/article/view/1945.

Mukhidin. 'Hukum Progresif Sebagai Solusi Hukum Yang Mensejahterakan Rakyat'. Jurnal Pembaharuan Hukum 1, no. 3 (2014): 267-86.

Murdan, Murdan. 'Pluralisme Hukum (Adat dan Islam) di Indonesia'. Mahkamah: Jurnal Kajian Hukum Islam 1, no. 1 (3 June 2016). https://doi.org/10.24235/mahkamah.v1i1.573.

Najih, Mokhammad. 'Dilemma Legal Pluralism in Indonesia: Prospects and Role of Islamic Law in the National Legal Reform'. Brighman Young University, Utah, US, 2016.

Nugroho, Wahyu, Imamulhadi Imamulhadi, Bambang Daru Nugroho, and Ida Nurlinda. 'Kebijakan Pengelolaan Tambang dan Masyarakat Hukum Adat yang Berkeadilan Ekologis'. Jurnal Konstitusi 15, no. 4 (15 January 2019): 816-35. https://doi.org/10.31078/jk1547.

Oetojo, Boedhi. Pluralisme, Sistem Sosial Budaya Indonesia. Jakarta: Universitas Terbuka, 2016.

Opusunggu, Yu Un. 'Arti Penting Hukum Antartata Hukum untuk Indonesia'. Jurnal Rechts Vinding: Media Pembinaan Hukum Nasional 7, no. 2 (31 August 2018): 147-68. https://doi.org/10.33331/rechtsvinding.v7i2.262.

Pawarti, Amin. 'Pelestarian Lingkungan Melalui Kearifan Lokal Lubuk Larangan Ngalau Agung (Studi Di Kampuang Surau Nagari Gunung Selasih Kecamatan Pulau Punjung Kabupaten Dharmasraya Provinsi Sumatera Barat)'. Masters, Program Magister Ilmu Lingkungan Undip, 2012. http://eprints.undip.ac.id/37843/.

hukumonline.com. 'Pluralisme Hukum Harus Diakui', 2 July 2006. https://www.hukumonline.com/berita/baca/hol15089/pluralisme-hukumharus-diakui/.

Ropii, Imam. 'Penghormatan Pluralitas Hukum Masyarakat Dalam Bingkai Hukum Nasional Sebagai Sarana Meneguhkan Integrasi Bangsa'. Jurnal Hukum Prasada 4, no. 1 (31 August 2017): 12-21. https://doi.org/10.22225/jhp.4.1.156.1-10.

Rozi, Mohammad Fahrur. 'Pluralisme Dan Multikulturalisme Dalam Membangun Masyarakat Madani; Kajian Paradigmatik'. $A L$ - IBRAH 2, no. 2 (31 December 2017): 104-27.

Safitri, Myrna A. 'Negara dan pluralisme hukum: Kebijakan pluralisme hukum di Indonesia pada masa kolonial dan masa kini'. In Beragam Jalur Menuju Keadilan: Pluralisme Hukum dan Hak-hak Masyarakat Adat di Asia Tenggara, edited by Marcus Colchester and Sophie Chao. Jakarta: Epistema Institute, 2012.

//perpustakaan.komnasham.go.id/opackomnas/index.php?p=show_detail \&id=11213\&keywords $=$.

Sarip, Sarip, and Abdul Wahid. 'Kemajemukan Visi Negara Hukum Pancasila Dalam Misi Hukum Negara Indonesia'. Refleksi Hukum: Jurnal Ilmu Hukum 
174 | De Jure: Jurnal Hukum dan Syar'iah, Vol. 12 No. 2 Tahun 2020

2, no. 2 (14 September 2018): 109-24. https://doi.org/10.24246/jrh.2018.v2.i2.p109-124.

Simarmata, Ricardo. Mencari Karakter Aksional Dalam Pluralisme Hukum. Jakarta: Huma Press, 2005.

Siradjuddin, Siradjuddin. 'Akar-Akar Konflik Fundamental Perspektif Ekonomi Politik'. Jurnal Iqtisaduna 1, no. 2 (19 December 2015): 17-39. https://doi.org/10.24252/iqtisaduna.v1i2.1192.

suddenlyproject. EKSPEDISI PULAU SABIRA: Konservasi Penyu \& Hasil Laut, 2019. https://www.youtube.com/watch?v=U82ZqyrfDKA\&t=186s.

Suhariyanto, Budi. 'Eksistensi Pembentukan Hukum Oleh Hakim Dalam Dinamika Politik Legislasi Di Indonesia'. Jurnal Rechts Vinding: Media Pembinaan Hukum Nasional 4, no. 3 (31 December 2015): 413-30. https://doi.org/10.33331/rechtsvinding.v4i3.14.

Sumardi, Dedy. 'Islam, Pluralisme Hukum dan Refleksi Masyarakat Homogen'. Asy-Syir'ah: Jurnal Ilmu Syari'ah dan Hukum 50, no. 2 (1 December 2016): 481-504. https://doi.org/10.14421/asy-syir'ah.2016.502-08.

Sumbulah, Umi, and Nurjanah Nurjanah. Pluralisme agama: Makna dan lokalitas pola kerukunan antarumat beragama. Malang: UIN Maliki Press, 2013. http://repository.uin-malang.ac.id/711/.

Swenson, Geoffrey. 'Legal Pluralism in Theory and Practice'. International Studies Review 20, no. 3 (1 September 2018): 438-62. https://doi.org/10.1093/isr/vix060.

Syawaludin, Muhammad. 'Memaknai Konflik Dalam Perspektif Sosiologi Melalui Pendekatan Konflik Fungsional'. Tamaddun: Jurnal Kebudayaan dan Sastra Islam 14, no. 1 (2014): 1-18.

Tamanaha, Brian Z. 'Understanding Legal Pluralism: Past to Present, Local to Global'. SSRN Scholarly Paper. Rochester, NY: Social Science Research Network, 3 September 2007. https://papers.ssrn.com/abstract=1010105.

Thomas, Vincent Fabian. 'Moeldoko Tuding OPM Manfaatkan Kerusuhan Papua'. tirto.id. Accessed 28 December 2020. https://tirto.id/moeldokotuding-opm-manfaatkan-kerusuhan-papua-egPw.

Ubaidillah, A., Dede Rosyada, Abdul Rozak, M. Arskal Salim GP, Wahdi Sayuti, and Andi Syafrani. Demokrasi,hak asasi manusia dan masyarakat Madani. Jakarta: ICCE UIN Syarif Hidayatullah Jakarta, 2000. //opac.fah.uinjkt.ac.id//index.php?p=show_detail\&id=797.

Wahyuni, Della Sri. 'Pluralisme Hukum Dalam Pembangunan Hukum Indonesia: Masalah Dan Tantangan Ke Depan'. LEIP (blog), 16 November 2015. https://leip.or.id/pluralisme-hukum-dalam-pembangunan-hukumindonesia-masalah-dan-tantangan-ke-depan-2/.

Wijayanti, Septi Nur. 'Hubungan Antara Pusat dan Daerah Dalam Negara Kesatuan Republik Indonesia Berdasarkan Undang-Undang Nomor 23 Tahun 2014'. Jurnal Media Hukum 23, no. 2 (2016): 186-99. https://doi.org/10.18196/jmh.2016.0079.186-199.

Wijayanto, Agustinus. 'Ternyata Ada Lubuk Larangan Di Sungai Subayang, Seperti Apa?' Mongabay Environmental News, 27 September 2018. https://www.mongabay.co.id/2018/09/27/ternyata-ada-lubuk-larangan-disungai-subayang-seperti-apa/. 
Yayan Sopyan, Urgency of Legal Pluralism...| 175

Yunus, Firdaus M. 'Konflik Agama di Indonesia Problem dan Solusi Pemecahannya'. Substantia: Jurnal Ilmu-Ilmu Ushuluddin 16, no. 2 (12 October 2014): 217-28. https://doi.org/10.22373/substantia.v16i2.4930.

Zainuddin, M. 'Urgensi Pendidikan Multikulturalisme'. www.uin-malang.ac.id. Accessed 27 December 2020. https://www.uinmalang.ac.id/blog/post/read/131101/urgensi-pendidikan-

multikulturalisme.html.

Zuriah, Nurul. 'Pendidikan Kewarganegaraan Multikultural Sebagai Wahana Pendidikan Hukum Dan Kesadaran Berkonstitusi'. Jurnal Wawasan Yuridika 23, no. 2 (28 October 2014): https://doi.org/10.25072/jwy.v23i2.13. 